\title{
EMBODYING COLLECTIVE MEMORY: TOWARDS RESPONSIBLE ENGAGEMENT WITH THE 'OTHER'
}

CH Thesnaar

Practical Theology and Missiology

Stellenbosch University

\begin{abstract}
In view of the current challenges to reconciliation and unity between the DRC and the URCSA this article attempts to join in the transdisciplinary discourse on cultural trauma and collective memory in order to find a way of dealing collectively with past traumas in a constructive way. It argues that the concepts of cultural trauma and collective memory are significant in dealing with distresses of the past, in order to create a collective memory, which implies taking responsibility for the present and the future. It further introduces a collective pastoral hermeneutics to assist both churches to take responsibility for the past by embodying collective memory shared with the 'other' in order to transform the past in the present for the future.
\end{abstract}

Key Words: Collective Memory; Trauma Fatigue; Church; Dealing with the Past; Pastoral Hermeneutics

\section{Introduction}

Shortly after the first free democratic elections in South Africa the Truth and Reconciliation Commission (TRC) engaged in a collective process to assist the nation in dealing with its destructive past by means of a collective ritual to mourn the losses of the past. This collective process is probably the most salient contribution from the TRC in South Africa. However, it becomes increasingly evident, given the extent of violence in South Africa today, that post-apartheid and post-TRC South Africa still have to face the challenge of acknowledging and working through historical losses in ways that affect various groups differently (LaCapra, 2001:699).

Against this background the ongoing struggle for church unity between the Dutch Reformed Church (DRC) and the Uniting Reformed Church of South Africa (URCSA) continues to be reminiscent of the legacy of Apartheid. The basic racial division between these two churches with very similar reformed confessions is a direct product of Apartheid. Although there are fundamental challenges within these two churches that need to be addressed it continues to be extremely difficult to comprehend why these two Christian churches still struggle to unite 18 years after the first free democratic elections.

In the DRC's document, Journey with Apartheid (1997), they committed themselves to improving the living conditions and future opportunities of people in South Africa who had been deprived of so much for so many years; to make a meaningful contribution to reconstruction and development; to commit to the ministry of reconciliation; to eliminate injustice at all levels and in all spheres of society; to combat poverty and illiteracy and be committed to restitution - the righting of the wrong that had been done. The URCSA also 
provided several significant suggestions concerning the possible role of the church $^{1}$ in contributing to reconciliation in South Africa (URCSA submission to the TRC, 1997:2123). These included pastoral counselling of victims of human rights violations, enabling perpetrators of crimes to confess their guilt and seek reconciliation, the preparation of reconciliation liturgies and the holding of services of reconciliation, the erection of appropriate memorials, implementing a "process of collective visioning", and holding an annual national week of reconciliation. Very little, if any, of both churches' commitment to reconciliation and unity has been honoured.

The above-mentioned raises some questions: Could the inability to keep to its commitments towards reconciliation and nation building made before the $\mathrm{TRC}^{2}$ suggest a nation still captured in the claws of collective trauma after the devastating impact of apartheid? Could trauma fatigue within these two churches therefore contribute to the lack of unity and reconciliation with the 'other ${ }^{3}$ ? Has the lack of dealing with the past become dysfunctional in the present within the DRC and the URCSA process of reconciliation and unity with the 'other'? Although these are fundamental questions they remain complex and therefore this contribution does not attempt to answer these questions but to rather reflect on their significance. This contribution will therefore attempt to explore the concept of cultural trauma and its relevance for understanding trauma fatigue within the post-Apartheid and post-TRC society; secondly, it will discuss the concept of collective memory and its relevance for dealing with the past; and lastly it proposes a collective pastoral hermeneutic to assist both churches to deal with the past in order to reconcile and to unite with the 'other'.

\section{Cultural Trauma and Trauma Fatigue}

Various disciplines ${ }^{4}$ have embraced the concept of trauma in the modern era and attempted to define it from their perspectives. The original meaning of the word trauma is derived from the Greek word, $\tau \rho \alpha \tilde{u} \mu \alpha^{5}$ meaning 'to wound' thus indicating a physical act of pain. Metaphorically and holistically it could also be understood as a psychological, emotional, physical, neurological or spiritual wound. Culbertson (1995:4) emphasises the physical dimension of trauma by explaining that it is always accompanied by violence that causes pain to the victim and causes the victim to be powerless against the overwhelming power that exceeds physical, cultural and social boundaries. In discussing Freud's 'Beyond the Pleasure Principle', Caruth (1996:2) indicates that trauma should also be understood as a double wound that could not be assimilated in the conscious mind at the time of occurrence and haunts the survivor afterwards. Therefore the story of trauma, according to Caruth (1996:7), is always two stories: "a double telling ... the oscillation ... between the story of the unbearable nature of an event and the story of the unbearable nature of its survival".

Also see the article by Rev Daniel Kuys, "Church needs to help reconcile" in Die Kerkbode, 12/13 September. 1997:5.

2 See Journey with Apartheid (1997:24) and the URCSA submission before the TRC, 1997.

3 'Other' refers to the opposite sides (URCSA (black) or DRC (white)) within the context of South Africa.

4 Disciplines such as psychology (See Van der Merwe \& Gobodo-Madikizela, 2007)); sociology (see Ericson, 1994; Alexander et al., 2004); history (see LaCapra, 1991); literature (see Anker, 2009, Caruth, 1996, Van der Merwe \& Gobodo-Madikizela, 2007); psychiatry (see Van der Kolk, 2002, Herman, 1992) and practical theology (see Louw, 2008).

5 See King James - Strong's Hebrew and Greek dictionary: from the base of $\tau ı$ to the base of G2352, G5147, G5149, etc.); a wound; wound 
This double wound can lead to dissociation with the actual trauma and cause disruption in consciousness, memory and identity.

In this regard Anker (2009:3) refers to the importance of recent neurobiological research in the working of the brain during traumatic experiences. In similar vein Wilkinson (2005) indicates that traumatic experience affects both the encoding and recall of the memories associated with them. In the brain's response to severe trauma, sensations of feeling, behaviour, images and meaning become dissociated from one another (Wilkinson, 2005:487). Thus when people relive their trauma, they have great difficulty in converting the experience into words (Van der Kolk, 2002:387; Brevin, 2003:117-123; Peres et al., 2005:433). It is because their bodies and minds will react with freezing ${ }^{6}$, numbing, detachment and forgetfulness when faced with similar danger or traumatic memories of the event (Williams, 2006:322). ${ }^{7}$ However, within the medical discipline neurobiological research continues to hold the promise that biomedicine will eventually cure and erase or undo this damage caused by trauma (Seeley, 2005:23).

The practical theologian, Daniel Louw (2008:94) introduces the spiritual dimension of trauma when he argues that spiritual trauma is a reality because it attacks the core of one's being. He explains: "When it influences one's understanding of God the whole theological and philosophical problem of theodicy surfaces, i.e. the question of how to relate suffering and evil with the love and justice of God. In spiritual trauma the meaning and purpose of life becomes vague, confused, or lost. The ability to connect with nature, mystery, love, people, the transcendent, is ruptured, and the effects of such brokenness surface". ${ }^{8}$ The spiritual dimension of trauma is of particular significance to the understanding of how the two churches were entangled in the trauma of the past in relation to their theological support or opposition to Apartheid and their struggle to reconstruct their theology within a post-Apartheid and post-TRC context.

Although the discussion thus far has focused on the impact of trauma on individuals, the question remains whether it is also applicable to the collective. In recent years there has been a shift from understanding the impact and effect of trauma on an individual, towards an understanding of the impact and effect of trauma on the collective. ${ }^{9}$ Veerman \& Ganzevoort (2001) are quite clear that individual and collective traumas are interrelated. According to them it is possible that collective trauma arises from a huge number of traumatized individuals within a community. In this way collective trauma then emerges from the pain that is radiated by traumatized individuals onto the community. Another possibility they add is that collective trauma might originate from an event that affects only a few individuals directly, but that threatens the structure and frame of reference of the community in ways that threaten the lives of individuals. They also add that in some cases, individual trauma could also be the consequence of collective trauma (Veerman \& Ganzevoort, 2001).

In his research on the importance of collective trauma, Alexander et al. (2004:1) developed a very helpful concept, 'cultural trauma'. Cultural trauma "occurs when members

See Van der Merwe \& Gobodo-Madikizela, 2007:25-27.

Also see Karen Sealy (2005:22) as she refers to the recurring nightmares, intrusive memories and emotional numbing, but stresses with other psychologists, the fact that trauma is fully embodied, "it literally gets under the skin and is engraved in the brain" and Brevin (2003:30): "Traumatic events are also accompanied by other powerful emotions, such as sadness and loss, betrayal, humiliation and anger".

8 Also see the work of Ganzevoort (2009:183-192) in this regard.

9 See the work of the sociologist Kai Erikson (1994:34) in this regard. 
of a collective feel they have been subjected to a horrendous event that leaves indelible marks upon their group consciousness, marking their memories forever and changing their future identity in foundational and irrevocable ways" (Alexander, 2004:1). Therefore cultural trauma does not only emphasize the existence of collective trauma but also the necessity to deal with trauma collectively. The indication that trauma has an effect on a group's identity in foundational and irrevocable ways affirms the cultural, religious and contextual significance of the collective trauma. However, it is also argued that these contextual, cultural and religious influences can influence resilience to the effects of trauma (Doxey, et al. 1997, Maercker \& Herrle 2003). A condition that can impede this resilience is 'trauma fatigue'. Trauma fatigue refers to a phenomenon occurring when people and support systems are over-exposed to cultural trauma and as a result, suffer from the effects of that trauma. The characteristics of trauma fatigue could include numbness, low levels of energy, loss of passion and meaning, forgetfulness, survival, preoccupation with selfidentity and inability to deal with the past and value the 'other'. In order to be resilient to the impact and effects of trauma, victims and perpetrators need to be able to break free from the shackles of 'trauma fatigue'. In this regard this article further wants to argue for a process of creating collective memory as a way of coping with the past and thereby transforming the impact of cultural trauma on the collective.

\section{Facing the Memories of the Past as a Collective}

Scholars from various disciplines recognized the impact of traumatic memory on individuals ${ }^{10}$ within diverse contexts. In this regard scholars should be aware of generalising trauma beyond its specific context. On the basis of Freud's theory, Caruth (2001:2) indicates that trauma consists of two moments: "the experience of something coming from outside, or the memory of it, that must be 'reinvested' in the second moment and then it becomes traumatic - it is the second reliving and memory that becomes traumatic, not the first act". Robson (2001:120) refers to the work of Janet (1925) who created the concept traumatic memory, and indicates that traumatic memory is inscribed on the body rather than in narrative memory and inaccessible to conscious recall. The explanation for such inaccessible trauma, or as Van der Merwe and Gobodo-Madikizela (2007:6) refer to it, deep memory, ${ }^{11}$ is that it cannot be verbalized because the language required to verbalize it has been torn apart by the trauma.

Kaminer (2006:484), however, argues that traumatic memories are the unassimilated scraps of overwhelming experiences which need to be transformed into narrative language: ${ }^{12}$ "traumatic memories, unlike other emotionally charged memories, are retrieved as sensory fragments with no verbal component". This is confirmed by Van der Merwe and Goboda-Madikizela $(2007: 15,25,26)$ finding that words and narrative formulation are ways of encoding trauma within the structure of language, to bring order into the experience of the fragmented and splintered condition following trauma. This raises the question whether (collective) memory ${ }^{13}$ operates in the same way in the collective ${ }^{14}$ as it does in individuals

\footnotetext{
10 See Anker (2009) in this regard.

11 See Charlotte Delbo's identification of intellectual/external memory and deep memory in Van der Merwe \& Gobodo-Madikizela (2007:6). Psychologists also distinguish between traumatic memory as: emotional memory, implicit memory, deep memory, episodic memory and sensory memories; while referring to the normal historical memory as: explicit, narrative, intellectual, external and semantic. 
dealing with the traumas of the past. These questions are not simple to answer and therefore this contribution will acknowledge their complexity, while remaining aware of the danger of using collective memory in a simplistic way. Hence I will attempt to engage carefully with the concept of collective memory. ${ }^{15}$ Within this context it is significant to acknowledge that collective memory is a useful concept and that all remembering occurs within social contexts of environment and discourse. ${ }^{16}$

The theory of Maurice Halbwachs on collective memory does offer some light in understanding this concept. In his work The Social Frameworks of Memory (1925) he developed the view that memory is collective and constructed within a social framework. This he explains by indicating that it is actually within the smaller groups within society that people acquire their memories. According to him "It is also in society that they recall, recognize, and localize their memories" (1925:38). He explains further that memory does not recall the real past, but only constructions of it; it 'distorts' the past in its need to show that an 'event' has a significance beyond the event itself. In this regard memory constructs the past for the present, especially in relation to one's social group. Social groups identify themselves and are identified by, their 'collective memories'. It is therefore understandable and inevitable that different groups may have different or even competing, versions of the same persons or events that could lead to the contestation of the memory.

According to Joseph Lam Cong Quy (2011:237) Halbwachs maintained that 'collective memory' is the heart of any group. Without collective memory society would cease to be. In this context an individual gains identity or meaning through participation in a social framework. The social group neither totally dispenses with, nor altogether determines, individual memory because it is the group members who remember $(1925: 43,51)$. In this sense individual stories are meaningful only when they are interpreted from collective memory, which provides a social framework for a meaningful interpretation of individual experiences (Joseph Lam Cong Quy, 2011:244). Memory is therefore not a property of the individual mind, but a diverse and shifting collection of material artefacts and social practices (Klein, 2000:130). Social memory provides the hermeneutical framework for meaningful communication and therefore presupposes the existence of memory prior to the formation of a social framework (Joseph Lam Cong Quy, 2011:244).

The social framework of the past is not preserved but rather reconstructed on the basis of the present even if the present is not necessarily stable. In this sense social frameworks are not constructed by adding together the various individual recollections, nor are they empty forms to be filled with recollections from elsewhere. Social frameworks, such as institutions, commemorative celebrations, festivals, etc. function at the same time as instruments for the use of the reconstruction of the past (Joseph Lam Cong Quy, 2011:244). For that reason social frameworks are flexible and dynamic; "One may say that the individual remembers by placing himself (herself) in the perspective of the group, but one may also affirm that the memory of the group realizes and manifests itself in individual memories" (Halbwachs, 1992:42). Therefore it is evident that every individual memory constitutes itself in communication with others. These 'others,' however, are not just any set of people; rather they are groups who conceive their unity and peculiarity through a common image of their past (Assmann \& Czaplicka, 1995:127). In Halbwachs' thinking,

\footnotetext{
14 In this contribution the concept 'collective' will be used to indicate families, communities, societies and nations.

15 See the work of K L Klein (2000:133) on memory in this regard.

16 See the work of K L Klein (2000:133) on memory in this regard.
} 
these 'others' are families, neighbourhood and professional groups, political parties, associations, etc., up to and including nations (Assmann \& Czaplicka, 1995:127).

Assmann \& Czaplicka (1995:127) introduce two concepts that help explain the formation of collective memory within groups, namely: communicative and cultural memory. Communicative memory ${ }^{17}$ indicates that a group bases its consciousness of unity and specificity upon this knowledge and derives formative and normative impulses from it, which allows the group to reproduce its identity. However cultural memory ${ }^{18}$ identifies socalled 'fixed points' that refer to fateful events of the past, memory of which is maintained through cultural formation (texts, rites, monuments) and institutional communication (recitation, practice, observance). They refer to these as 'figures of memory.' A key aspect of their theory of cultural memory attempts to relate what they call three poles: memory (the contemporized past), culture, and the group (society), to each other (Assmann \& Czaplicka, 1995:127). In order to explain how these are related to each other they refer to certain characteristics of cultural memory, namely: the relation to the group; the capacity to reconstruct; formation; organisation; obligation and reflexivity. ${ }^{19}$ Due to the limitations of this article these characteristics cannot be discussed apart from concluding that the collection of memories is shared by a common culture.

In this regard Holtschneider (2001:21) reminds us that memories and the conflicts within memories are inherited by subsequent generations because memories influence communal and individual identity. This identity is passed on through generations, therefore indicating that memories from the past still have an influence in the present. In this regard LaCapra (2001:186) indicates that the present and the past should be seen as metaphorical, as the present is understood in terms of the past and vice versa (Borbelly, 1998:925; Modell, 2003:562). The connection between the struggles of the past and the present is therefore decisive in understanding the process of remembering in many contexts today. This resonates with the reasoning of Assmann (2007:38) with reference to collective memory within the European states, that the outcome should not be "a master narrative nor a common history textbook for all member states, but a generally agreed-upon frame of reference that is needed to communicate and negotiate conflicting memories. This common frame of reference is needed not in order to abolish distinctive national narratives and memories, but in order to diminish the destructive differences of national memories by making them compatible with each other". Therefore, in order to understand the process through which collective memory is produced, it is necessary to focus on the current experiences, interests and needs of the different actors involved in this process (Van Drunen, 2010:34). This is very relevant because what actors of memory decide in the present and in the future is determined by what they consider important to remember or forget from the past. $^{20}$

All actors within a particular context need to participate in the process of determining the common frame for creating collective memory. The memories of all the actors need to

17 The communicative memory offers no fixed point which would bind it to the ever-expanding past in the passing of time.

18 Just as the communicative memory is characterized by its proximity to the everyday, cultural memory is characterized by its distance from the everyday. Distance from the everyday (transcendence) marks its temporal horizon. Cultural memory has its fixed point; its horizon does not change with the passing of time (Assmann \& Czaplicka, 1995:127).

19 See Assmann \& Czaplicka (1995:129) in this regard.

20 Also see the work of Holtschneider (2001:19) in this regard. 
find their way into the public space so that they can be legitimized and recognized as part of the national memory. The process of creating collective memory should not be understood as a synonym for the process historians will use to write history. Within the context of dealing collectively with the traumas of the past ${ }_{2}$ memory should always be understood as relational, personal, subjective, narrative, healing, transformative and social. For this reason memory cannot be limited to political memory. Memory is also moral, ${ }^{21}$ existential and spiritual. For Memory to find its way into the public space it needs to be maintained at all costs, and not relegated to oblivion and silence. It should be actively interiorised by all actors in order to own the collective memory. For ownership to take place a collective need, what Levy and Sznaider (2005:291) call a 'collective consciousness' must be shared among all involved, to deal with the construction and representation of trauma in collective rather than individual terms.

There is a real danger that the creation of collective memory can be distorted by actors in the process either to manipulate what should be remembered or by applying silence. Actors with power will, in a time of crisis, use rumour, media and other types of propaganda for political gain in the present. In this regard a government is always in the privileged position to impose its narrative, displace other narratives, in order to build national identity as they envisage it. ${ }^{22}$ As the dominant actor they will mostly not agree to any counter-memories from other actors. The state will then use its political power to task its national education system to educate the nation with an official history in order to reinforce the social order, and this will be supported with the creation of patriotic symbols, monuments, commemoration sites and the renaming of streets, cities, buildings etc. In this way past trauma will be institutionalised by those in power. But even if there are vast differences $^{23}$ among the actors in terms of how they should deal with the past or what their expectations are of the process of dealing with the past, it should never derail the creation of collective memory. The Argentinian process of dealing with their past provides us with an example of coping constructively with differences by emphasising the importance of collaboration between the survivors, human rights organisations and the government. This collaboration formed a key part in understanding the way people wanted to mourn their loved ones, how widespread the repression was and to assist in securing memory over time (Van Drunen, 2010:115).

Communities and nations seeking to establish collective memory should take cognisance that archives, museums and monuments continue to be but one of various means of constructing memory. Keeping memory alive within the collective is probably the most significant way of creating and transforming collective memory. The Argentinian process affirms this by emphasising that it needs to be a daily practise to transmit memory within the public scene by means of talks at schools, or at conferences or in participation in marches and other public activities (Van Drunen, 2010:118). Groups in Argentina participated actively to work on memory in their neighbourhoods to establish memory marks in the public space as a means to counter denial and impunity and at the same time trigger collective forms of remembering (Van Drunen, 2010:162). When past memories come alive in the present it becomes possible to face those memories and transform them in the present in order for them to become living or embodied memory for future generations.

\footnotetext{
21 Also see the work of Holtschneider (2001:18) in this regard.

22 Holtschneider (2001:13) indicates in this regard that the official interpretation and resonance of National Socialism was planned and engineered by the GDR government.

23 Also see Van Drunen (2010:34) on mnemonic battles.
} 
Collective memory as living or embodied memory can then become a vehicle to address political and social transformation in the present for the future.

\section{Collective Pastoral Hermeneutics}

Based on the argumentation thus far this contribution wishes to argue for a collective pastoral hermeneutics that will guide the DRC and the URCSA to deal with the past traumas as a collective and to participate in the process of creating collective memory - not merely because they share the common history ${ }^{24}$ but because they live in the present and can therefore play an active role in facilitating this process.

A collective pastoral hermeneutics within the South African context acknowledges the existence of cultural trauma as indicated earlier and accepts the responsibility to understand and interpret it as part of a transdisciplinary ${ }^{25}$ process and not to deal with cultural trauma in isolation. A collective pastoral hermeneutics will further be contextual in its approach and will therefore deal with cultural trauma from an intercultural pastoral paradigm ${ }^{26}$. Theologically it's about remembering the story of the compassion of Jesus Christ. In this regard the theology of the cross reveals the passion and compassion of a suffering God (Louw 2008:441) and the resurrection of Christ provides the basis for the redemption of the past and brings hope and meaning to the present and the future. Ethically the passion and compassion of Jesus Christ means placing the 'other' in the centre. Pastorally it is about creating a community that is concerned with compassion, respect for others, sensitivity, empathy, "interpathy", unconditional love, listening with understanding and actively participating in the creation of a collective memory. It is ultimately about the creation of a community which will emphasize the collective transformation of the past, because it is all about our human quest for importing meaning, human dignity and hope. ${ }^{27}$ This community, the church, can then become what Fazakas (2011:1) calls an 'island of freedom', a 'sheltered space' for meeting and reworking the past. Based on the above explanation a collective pastoral hermeneutics within the church context will emphasize the following:

\section{- Collective Memory as a Theological Concept}

A collective pastoral hermeneutics identifies with the notion of cultural trauma and memory as a collective concept. Memory, in which remembrance rituals have a central function, forms an essential part of the Judaic and Christian traditions (Vosloo, 2009:280). In this way Christian memorial practices anchor Christian rituals in a Christian community. The commitment that God will not forsake nor forget his people is cemented within the covenant and forms a fundamental part of the Christian identity. The South American theologian, Gutiérrez (1983:12) highlights that memory based on the deeds of Yahweh is a reaffirmation of hope and in that way conditions a creative liberty. Christian memory connects Christology with Pneumatology and safeguards not only the distinctiveness, but also the universality of the salvific significance of Jesus Christ (Lam Cong Quy, 2011:248). This therefore entails that memory can become liberating and redemptive because it is based on the covenant and actions of God in Jesus Christ with his people in the past,

\footnotetext{
24 See Van der Merwe, (2003:269-281) in this regard.

25 See the contribution by Leiner, M \& S Fläming (2012:21-28) in this regard.

26 See the contribution by Thesnaar (2012:215-230) on a Pastoral hermeneutical approach to reconciliation and healing.

27 See Louw (2008:158) in this regard.
} 
present and future. This is emphasised by Vosloo (2009:1) when he states that the past, as the story of God's faithfulness, is recalled time and again as an identity-strengthening resource for life in the present. For this to be possible the past needs to be collectively remembered, interpreted and celebrated.

At the conclusion of her research on the memories of the Holocaust Holtschneider (2001:198) refers to the German theologian, Jüngst who suggests that the formulation of theology should facilitate the articulation of the inherited memories which have been influential in shaping the self-understanding of Germans and Jews in relation to the Holocaust. Applied to the South African context it challenges theologians to develop a theology that should facilitate the articulation of the inherited memories which have been influential in shaping the self-understanding of South Africans within the DRC and URCSA in relation to Apartheid.

\section{- Collectively Facing the Past}

A collective pastoral hermeneutic would advocate that actors seize responsibility for the past, the present and the future. This implies that the DRC and the URCSA will need to take responsibility and be accountable ${ }^{28}$ for their role in the Apartheid past, either as victims, perpetrators or both. In this regard Pollefeyt (2004:158) argues for a change from 'collective guilt' to 'collective responsibility'. According to him nobody carries personal guilt for what generations have done before them. People therefore cannot be identified with the history of their family or community, even if they benefited from the unjust deeds of their forefathers (as in colonialism). However, the victims of the past will see the descendants of these unjust deeds as responsible for the past. Although the decendants of perpetrators cannot be personally guilty of the past they do carry collective responsibility for the past and therefore for responsibility for the present and the future. In this regard victims also need to take responsibility to face the traumas of the past in order to ensure that they are not sucked into a vicious cycle of becoming perpetrators of 'others'.

A collective pastoral hermeneutics will therefore be sensitive to the existence of mnemonic battles between the different actors on either sides of the divide as well as between actors on the same side, in the process of creating collective narratives of the past. Therefore there needs to be a constant awareness of the way we manipulate memory in service of our search for identity (Vosloo, 2009:5). It is acknowledged that it is very difficult, almost impossible to formulate memories that do justice to both sides of any divide in a post-conflict or post-crisis context. In relation to the earlier discussion it is clear that personal and collective memories are interwoven with those of other people, groups and nations. Others are therefore not only part of our memories, but we are also part of theirs (Vosloo, 2009:7).

Holtschneider (2001:197) concluded that although many second generational theological texts in Germany expressed the need for direct communication with Jewish men and women in order to share each other's lives, there was an absence of such encounters in German society. Instead they were so preoccupied with reconstructing their own identities after the Holocaust had shattered Christian self-understanding that they did not listen to the 'Jewish other' and acknowledge their experiences and interpretations of the Holocaust (Holtschneider, 2001:197). The process of creating collective memories of the past cannot take place without the 'other'. The 'other' will therefore assist us to take thorough account

28 See the four elements of Niebuhr on responsibility in Osmer, 2008:140. 
of the strategy of exclusion that is linked to the fragility, and also the wickedness, of our memory (Vosloo, 2009:8). Applied to the South African context constructive spaces need to be created where members of the DRC and the URCSA can meet as a collective to interact with the traumas of the painful past in order to create collective memories. In this regard both churches will need to battle actively against exclusion of the 'other', the notion of forgetting the distortions in representations of the 'other'. Grob (2008:74) warns against actively avoiding the risk of objectifying the other, and therefore he contends that the metanarratives must be transformed into 'inter-narratives', 'inter-myths'. These inter-myths are not fixed but need to be continually formed and reformed in the spaces between the members of the two churches. These spaces filled with compassion are to allow for the recognition of the 'other' and, significantly the desire to be transformed by the 'other'. Theologically collective memory would therefore contribute to reconstructing identities in co-operation with each other, with wisdom.

\section{- Collectively Mourning the Cultural Traumas}

A collective pastoral hermeneutics is aware of the danger un-narrated trauma can impose on generations at all levels of their existence. Essentially, it focuses on ways for traumatized people to work through ${ }^{29}$ the traumas of their past, in order to avoid becoming victims of the past and victimizers in the present. In this regard he indicates that mourning brings the possibility of engaging with trauma and achieving a reinvestment in - or recathexis of - life that allows one to begin again (LaCapra, 2001:713).

Memory is fundamental for the collective to mourn their past traumas. Mourning is a process that attempts to assist victims to restore the dignity that was denied them by their victimizers. It is, however, also a process for perpetrators to take responsibility for the trauma they have caused, to restore the harm that was done and to participate actively in the creation of collective memories. Through memory-work, especially the socially engaged memory-work involved in working-through, people are able to distinguish between the past and present and to recognize something as having happened to them back then that is related to, but not identical with, the here and the now (LaCapra, 2001:713). LaCapra continues that mourning involves a different inflection or performativity: a relation to the past that involves recognizing its difference from the present - simultaneously remembering and taking leave of or actively forgetting, thereby allowing for critical judgment and a reinvestment in life, notably social and civic life with its demands, responsibilities and norms requiring respectful recognition and consideration for others (LaCapra, 2001:716).

Concerning the South African context, Dr Elma Ross (in Van Bart, M 2012) conducted research on the trauma of the concentration camps during the Anglo Boer War. She suggests that the historical trauma might be seen as a founding trauma that could be identified as one of the causes of the Apartheid system, due to the lack of acknowledgement, working through circumstances and mourning. She indicates that the survivors never dealt with the trauma of the concentration camps, it was simply carried over to the next generation. She concludes by stating that the Apartheid system was one of the negative consequences of this unresolved suffering ${ }^{30}$. In terms of the theory on mourning the traumas of the past one could conclude that the Afrikaners could not reform because they

29 See LaCapra (2001:699) discussion of the concepts absence and loss.

30 See the article by M van Bart (2012) and the disappointment of the lack of a TRC after the Anglo Boer War uttered by Krog (in Huyse, 2006:136) in this regard. 
did not mourn their past traumas. Without openness towards your collective story, mourning is impossible. ${ }^{31}$ Although this does create a measure of understanding that their incapacity to transform is connected with the incapacity to mourn it cannot in any way be a justification for what was done during Apartheid. Apartheid was also viewed by the TRC as a historical trauma related to particular or specific events where the victims were urged to situate the founding trauma that paradoxically becomes the basis for collective and/or personal identity. However, the research done by Levy and Sznaider (2005:289) does make us aware of the fact that Apartheid, as well as the Holocaust, have become dislodged from their historical contexts and have come to signify a universal code of suffering. The danger here is the emphasis it places on the universal applicability of the trauma rather than on its historical specificity. This has the tendency to confuse the actors in the present to lose the focus of the direct effect of the historically specific trauma of Apartheid on those involved.

\section{- Collective Utilization of Rituals, Metaphors and Symbols}

Pollefeyt (2004:158) defines reconciliation as "Actively giving the wounds of perpetrators and victims the chance to heal by means of symbols and rituals, so that both parties can find their humanity together and share it with each other." Utilizing metaphors, symbols and rituals is therefore a creative and constructive way for both churches to deal collectively with the past. The value of a metaphor is situated in creatively utilizing language to communicate meaning which cannot be expressed in a rational language. Creative written language empowers both the victim and the perpetrator to remember and express the past in an aesthetic, poetic and mystic way. A symbol fulfils a bridge function, via the representation of an image, between the reality of faith and human experience in the world. ${ }^{32}$ Therefore a symbol refers to another reality. The actions of human beings have specific images to which they can relate certain experiences. These experiences can then be linked for example to religious symbols ${ }^{33}$ such as the cross, the dove, meditation, cathedrals, the laying on of hands and anointment. Karecki (1997:601) describes a ritual as "endemic to both individual and community life. It is the storehouse of a community's central values, or root metaphors of a community or culture." In this regard the value and impact of a ritual (such as the communion, reburial rituals, etc.) to remember, transform, affirm identity, and bring meaning should not be underestimated. It has the ability to challenge the actions of a whole community to evaluate its action in the presence of the broader community in relation to its basic religious identity. Symbols, metaphors and rituals should not be limited to the well-known ones but the collective should create new relevant and contextual symbols, metaphors and rituals continuously to deal with the past. These would indicate the road where there is no road visible.

\section{- Collectively Transforming the Past}

A collective pastoral hermeneutics will need to engage with the past in a critical way in order to transform the past in the present and the future. Vosloo (2009:5) affirms that it is precisely the interaction with the past in all its strangeness that could help us in a surprising manner to gain perspective on ourselves in the present. In the earlier discussion the reality of intergenerational memory transmission has been acknowledged. The implication thereof is that later generations have inherited discourses of memories that have been interpreted in

See Pollefeyt (2004:154) in this regard.

See Louw (1997:60) in this regard.

See Berinyuu (1988:96) in this regard. 
relation to their understanding of the past trauma. The present generation will therefore need to recover what has been destroyed by previous constructions of memory and they will need to reinterpret and transform it. Applied to the current generation in South Africa it challenges the DRC and the URCSA members to deal with their self-understanding in relation to the past but also to the memories they inherited from the past. They will then need to interpret these memories within the current context with the 'other' in order to transform it into collective memories.

The goal of collective memory cannot be limited only to creating memorials or museums to remember to past. It calls on communities to embody memory, participate in processes, integrate memory in our existence, popularise memory in our daily living in order to assure that collective memory becomes a vehicle for achieving social and political transformation. This momentum will contribute actively towards overcoming the "trauma fatigue' experienced by both churches in the present. Applied to the South African context the ultimate goal of the DRC and URCSA cannot be only to reconcile and unify but must include the use of their collective memory to lobby and network for achieving social and political transformation.

\section{Conclusion}

Based on the discussion on cultural trauma and collective memory it is clear that the questions raised in the beginning of this contribution are more complex than anticipated. However, it is evident that cultural trauma is a reality within the DNA of the two churches. The danger is therefore that if both churches fail to deal with the cultural trauma they run the risk of being captured in the past in such a way that it can cause signs of destruction and unjust behaviour in the present. The contribution provides some avenues for these churches as a collective to break through the 'trauma fatigue' and participate in a process to narrate their past memories in order to create collective memories with the 'other' that will assist them in dealing with the past in the present.

In this regard it emphasises that both churches can play leading roles in assisting the collective to develop a collective memory to deal with the cultural trauma. Therefore this article has argued for a collective pastoral hermeneutics to assist the churches in this prophetic role. A collective pastoral hermeneutics accepts that collective memory is embedded in theology; acknowledges that the past needs to be faced together with 'the other'; emphasises that past traumas should be mourned collectively and that all actors should participate to transform the past into the present on the way to the future. As moral communities both churches need to be reminded constantly of their responsibility toward the 'other' and then only can the 'other' become my care, my calling and indeed my responsibility. A collective pastoral hermeneutics reminds us that God, through His Son and the Holy Spirit, has always been faithful to His covenant with the collective (all human beings) and that the suffering and resurrection of Christ is reminiscent thereof. As the Church collectively participates in the process of dealing with past traumas and engaging with the process of developing collective memories we must remember that our actions are incorporated in God's actions. These two churches can contribute to the creation of a collective memory within the broader South African society if they are able to demonstrate this within their own contexts and therefore adhere to the plea of Graça Machel (2012:1), for a vision to build a healthy society in order to heal the character of sons and daughters of our beloved nation. 


\section{BIBLIOGRAPHY}

Alexander, JC, R Eyerman, B Giesen, NJ Smelser \& P Sztompka 2004. Cultural Trauma and collective identity. Berkeley: University California Press.

Anker, J 2009. Metaphors of pain: the use of metaphors in trauma narrative with reference to Fugitive Pieces. In Literator, 30(2).

Assmann, J and J Czaplicka, 1995. Collective Memory and Cultural Identity. In New German Critique, No. 65, Cultural History/Cultural Studies (Spring-Summer, pp. 125-133. Published by: New German Critique Stable URL: http://www.jstor.org/stable/488538 Accessed: 21/06/2012.

Assmann, A 2007. Response to Peter Novick. In GHI Bulletin No. 40. Spring 2007:33.

Brevin, CR 2f003. Post-traumatic Stress Disorder. Michigan: Vail-Ballou Press.

Caruth, C (ed.) 1995. Trauma. Explorations in Memory. London: The Johns Hopkins University Press.

Caruth, C 1996. Unclaimed experience: Trauma, narrative and history. Baltimore: The Johns Hopkins University Press.

Caruth, C 2001. An Interview with Jean Laplanche.

http://www3.iath.virginia.edu/pmc/text-only/issue.101.2caruth.txt. Date of Access: 26/10/2012.

Culbertson, R 1995. Embodied memory. Transcendence, and Telling: recounting trauma, re-establishing the self. In New Literary History, 26:1 (Winter).

http://www.accessmylibrary.com/article-1G1-16630367/embodied-memorytranscendence-and.html. Date of Access: 28/09/2012.

Gutiérrez G 1983. The Power of the Poor in History. New York: SCM Press.

Doxey, C, Jensen, L, \& Jensen, J 1997. The influence of religion on victims of childhood sexual abuse. International Journal for the Psychology of Religion, 7(3):179-186.

DRC - General Synodal Commission, 1997. Journey with Apartheid. Wellington: Hugenote Publishers.

Ericson, K 1994. New Species of trouble. Explorations in disaster, trauma and community. New York: Norton.

Fazakas, S 2011. Reconciliation with the past as path for the future? On the relationship between church and society in today's Hungary. http://www.theologie.unigreifswald.de/fileadmin/mediapool/RNE_Abstract_Fazakas.pdf. Accessed: 03/12/2012.

Ganzevoort, RR 2009. 'All things work together for good'? Theodicy and post-traumatic spirituality. In Secularization Theories, Religious Identity, and Practical Theology. Gräb, W \& Charbonnier, L (eds.). Münster: LIT-Verlag, 183-192.

Guard hacked to death at KZN mine, News24 2012. [Online]. Available: http://www.news24.com/SouthAfrica/News/Guard-hacked-to-death-at-KZN-mine20121003 [10/3/2012].

Grob, L 2008. 'Forgetting' the Holocaust: Ethical dimensions of the Israeli-Palestinian conflict. In Grob L \& JK Roth (ed.). Anguished hope: Holocaust Scholars Confront the Palestinian-Israeli conflict. Grand Rapids: Eerdmans, 68-83. 
Halbwachs, M 1925.'The social frameworks of memory', in LA Coser (ed. and transl.), On collective memory, pp. 35-189, University of Chicago Press: Chicago.

Halbwachs, M 1992. On Collective Memory, edited and translated, and with an Introduction by Lewis A. Coser, Chicago: University of Chicago Press, 42.

Herman, J 1992: Trauma and Recovery. From domestic abuse to political terror. London: Pandora.

Holtschneider, KH 2001. German Protestants remember the Holocaust. Theology and the construction of collective memory. Münster: LiTT Verlag.

Huyse, L 2006. All things pass, except the past. Leuven: Awepa.

Kaminer, D 2006. Healing Processes in Trauma Narratives: A Review. In South African Journal of Psychology, 36(3):481-499.

Karecki, M 1997. Religious ritual as a key to wholeness In Missionalia 25(4):598-606.

King James Bible Strong's Hebrew and Greek Dictionary Index, 2000.

http://www.sacrednamebible.com/kjvstrongs/STRINDEX.htm. Accessed on the $28^{\text {th }}$ of September 2012.

Klein, KL 2000. On the emergence of memory in historical discourse. In Representations 69. Winter:127-150.

Kuys, D 1997. “Kerk moet help versoen”. Die Kerkbode, 159:5 (no. 6).

LaCapra, D 1991. The bounds of race. Perspectives on hegemony and resistance. Ithaca: Cornell University Press.

LaCapra, D 2001. Trauma, Absence, Loss. In Critical Enquiry, 25:696-727, Summer.

Lam Cong Quy, JL 2011. Maurice Halbwachs' 'Collective Memory' and Contemporary Approaches to Theology. In Australian e Journal of Theology, 18.3:236.

Leiner, M \& S Fläming (ed.), 2012. Latin America between conflict and reconciliation. Göttingen: Vandenhoeck \& Ruprecht.

Levy, D \& N Sznaider, 2005. The politics of commemoration: The Holocaust, Memory and Trauma. Pp. 289-297.

Louw, DJ 2008. Cura Vitae. Cape Town: Lux Verbi.

Machel, C 2012. Machel calls for SA to face its demons by setting up new TRC. In The Argus, 13/10/2012, 1.

Maercker, A \& Herrle, J 2003. Long-term effects of the Dresden bombing: Relationships to control beliefs, religious beliefs, and personal growth. In Journal of Traumatic Stress, 16:579-587.

Peres, J, Mercante, J and Nasello, G 2005. Psychological dynamics affecting traumatic memories: implications in psychotherapy. In Psychology and Psychotherapy: Theory, Research and Practice, 78:431-447.

Pollefeyt, D 2004. Forgiveness after the holocaust. In: After-words: Post-holocaust struggles with forgiveness, reconciliation, justice. D Patterson \& J Roth (ed.), Seattle: University of Washington Press, pp. 55-72.

Pollefeyt, D 2004. Ethics, forgiveness and the unforgivable after Auschwitz. In: Incredible forgiveness. Christian ethics between fanaticism and reconciliation. D Pollefeyt. Leuven: Peeters (pp. 121-159).

Robson, K 2001. Curative Fictions: the 'Narrative Cure' in Judith Herman's Trauma and Recovery and Chantal Chawaf's Le manteau noir. In Cultural Values, Vol 5 No 
1:115-130. Ricoeur, P, Memory, History, Forgetting. Chicago: University of Chicago Press, 2004:82.

Seeley, K 2005. Trauma as a Metaphor: The Politics of Psychotherapy after September 11. In Psychotherapy and Politics International, 3(1):17-27.

Thesnaar CH 2012. A Pastoral hermeneutical approach to reconciliation and healing. In Latin America between conflict and reconciliation. Leiner, M \& S Fläming (ed.), Göttingen: Vandenhoeck \& Ruprecht.

URCSA submission before the TRC, 1997: Unpublished.

Van Bart, M 2012. Terreurkampe en erf-trauma. In Die Burger, 08/09/2012.

Van der Kolk, BA 2002. Posttraumatic Therapy in the Age of Neuroscience. In Psychoanalytic Dialogues, 12(3):381-392.

Van der Merwe, H 2003. The Role of the Church in Promoting Reconciliation in Post-TRC South Africa. In Religion and Reconciliation in South Africa, Chapman, A \& Spong, B (eds), 269-281, Philadelphia: Templeton Foundation Press.

Van der Merwe, C \& Godobo-Madikizela, G 2007. Narrating our Healing. Perspectives on Working through Trauma. Newcastle: Cambridge Scholars Publishing.

Van Drunen, S 2010. Struggling with the past. The human rights movement and the politics of memory in post-dictatorship Argentina (1983-2006). Amsterdam: Rozenberg.

Veerman, AL \& R Ganzevoort, 2001. Communities Coping with Collective Trauma. Paper presented at the 2001 conference of the International Association for the Psychology of Religion, Soesterberg, The Netherlands.

Vosloo, R 2009. Memory, tradition, theology: En route to a responsible historical hermeneutics. Presentation at the Theological Day, Faculty of Theology, Stellenbosch University, 2 February 2009.

Wilkinson, M 2003. Undoing Trauma: Contemporary Neuroscience. In Journal of Analytical Psychology, 48:235-253.

Wilkinson, M 2005. Undoing Dissociation. Affective neuroscience: a contemporary Jungian clinical perspective. In Journal of Analytical Psychology, 50:483-501.

Williams, W I 2006. Complex trauma: Approaches to Theory and Treatment. Journal of Loss and Trauma, 11:321-335. 